excarsion with the Botanical Section to demonstrate the agricultural soils of Kent was conducted by B. S. Furneaux.

The Zoological Section, under the presidency of Major Maxwell Knight, held a symposium on Nature study, with particular reference to the need for co-operation between the museum, laboratory and field-worker. The leaders on the Stodmarsh-Trenley Park Wood excursion were D. Stainer and R. G. Williams, and the Rev. Laurens Sargent led the Section on an expedition to the estuary of the Stour near Richborough. An evening was devoted to a conversazione arranged by the local committee. The exhibits included manuscripts shown by the Dean and Chapter and the charters of the King's School. Land, freshwater and marine life in all sections were displayed.

The 'Young Naturalists' Evening' commenced with a 'brain's trust' consisting of a team of experts, L. C. Bushby, Dr. L. B. Langmead, F. Rose and David Seth Smith, with Major Maxwell Knight as question master. Many questions received from students of local schools were answered. An exhibition of Nature films taken at the London Zoo by Douglas Fisher was enthusiastically received by an audience from the schools, the hall being filled to capacity.

The next congress will be held jointly with the South-Western Union at Marlborough during Whitsuntide, 1950.

\section{NATIONAL ACADEMY OF SCIENCES, UNITED STATES}

$\mathrm{T}$ HE National Academy of Sciences at its annual meeting held in Washington, D.C., during April 25-27, elected the following officers, members and foreign associates.

Vice-president for a four-year term ending in 1953 : Edwin Bidwell Wilson, emeritus professor of vital statistics, Harvard School of Public Health, Boston, Moss.

Members of the Council of the Academy for a threeyear term ending in 1952: Joel H. Hildebrand, professor of chemistry, University of California; Ernest W. Goodpasture, professor of pathology and dean, School of Medicine, Vanderbilt University.

Members : George W. Bartelmez, professor of anatomy, University of Chicago ; Frank A. Beach, professor of psychology, Yale University; Robert B. Brode, professor of physics, University of California; Paul R. Burkholder, Eaton professor of botany, Yale University; Lowell T. Coggeshall, professor and chairman, Department of Medicine, and dean, Division of Biological Sciences, University of Chicago; Max Delbrück, professor of biophysics, California Institute of Technology; Robert C. Elderfield, professor of chemistry, Columbia University ; William F. Gibbs, vice-president, Gibbs and Cox, 240 East 79th Street, New York; William W. Hansen, professor of physics, Stanford University; Charles B. Huggins, professor of surgery, University of Chicago ; Walter D. Lambert, U.S. Coast and Geodetic Survey (retired), Washington, D.C. ; Howard B. Lewis, professor and head of Department of Physiological Chemistry, University of Michigan; Francis W. Loomis, professor and head of Department of Physics, University of Illinois; Thomas S. Lovering, U.S. Geological Survey, Washington, D.C. ; Samuel M. McElvain, professor of chemistry, University of Wisconsin Saunders MacLane, professor of mathematics, University of Chicago ; Nicholas U. Mayall, Lick Observatory, Mt. Hamilton, California; Otto Meyerhof, research professor of physiological chemistry, University of Pennsylvania; John S. Nicholas, Sterling professor of biology, Yale University; George B. Pegram, professor of physics and dean of graduate faculties, Columbia University; Kenneth S. Pitzer, professor of chemistry, University of California; Kenneth B. Raper, senior microbiologist, Northern Regional Research Laboratory, U.S. Department of Agriculture, Peoria, Illinois; John L. Savage, chief designer, U.S. Bureau of Reclamation, Denver, Colorado; Carl F. Schmidt, professor of pharmacology, University of Pennsylvania ; Julian Schwinger, professor of physics, Harvard University; Harry L. Shapiro, professor of anthropology, Columbia University ; Oliver R. Wulf, professor, Division of Chemistry and Chemical Engineering, California Institute of Technology ; Ralph W. G. Wyckoff, scientist director, National Institute of Health, Bethesda, Maryland; Frederick W. H. Zachariasen, professor and chairman of the Department of Physics, University of Chicago.

Foreign Associates: Élie Cartan, professor of geometry, University of Paris; Paul A. M. Dirac, Lucasian professor of mathematical physics in the University of Cambridge ; Bernard Lyot, astronomer, Meudon Observatory, Seine-et-Oise, France; Henri Piéron, Laboratory of Physiological Psychology, Sorbonne; Arne Tiselius, professor of biochemistry, University of Uppsala; Öjvind Winge, director, Department of Physiology, Carlsberg Laboratory, Copenhagen; Hideki Yukawa, professor of physics, Kyoto University, Japan.

\section{Awards for 1948}

The Academy has made the following awards for 1948 .

Cyrus B. Comstock Prize of 3,500 dollars: to Dr. Merle Anthony Tuve, director of the Department of Terrestrial Magnetism of the Carnegie Institution of Washington, for his pioneering work on the upper atmosphere and his development of the electrical impulse method of study ; for his pioneering work in nuclear physics utilizing the electrostatic generator; and for his development of the proximity fuse.

James Craig Watson Gold Medal : to Dr. Samuel Alfred Mitchell, director for more than thirty years of the Leander McCormick Observatory of the University of Virginia, for distinguished services to astronomy, including (1) observations of solar eclipses, in particular a detailed study of the spectrum of the chromosphere which has contributed notably to knowledge of the atmosphere of the sun; (2) determination of the magnitudes of eight thousand comparison stars in 450 fields containing long-period variables, and more than fifteen thousand observations (with others) of 204 of the variables themselves ; (3) trigonometrical measurement of the parallaxes of some fifteen hundred stars.

Mary Clark Thompson Gold Medal : to Dr. Frank McLearn, of the Geological Survey of Canada, in recognition of his important contributions to geological knowledge in a number of fields.

Public Welfare Medal: to Prof. George Harrison Shull, emeritus professor of botany and genetics, Princeton University, for his services in the application of principles of the pure line and of hybrid vigour to the improvement of the quantity and quality of the maize crop. 